\title{
Experience in Poverty Reduction in the World and Lesson for Vietnam
}

DOI: https://doi.org/10.47175/rissj.v2i2.219

\section{| Dang Huu Dung |}

Ph.D.Candidate of Graduate Academy of Social Sciences, Vietnam

dangdungulsa@gmail.com

\begin{abstract}
Vietnam is a country that is considered to have certain successes in poverty reduction. However, poverty is still very concerned and is always one of the hot issues of society. Through the study of documents, this article aims to learn about effective poverty reduction activities of countries around the world so that we can learn from the experiences, good lessons of these countries to apply in reducing effectively poverty in Vietnamese. The results of the literature review show that poverty reduction should rely on the internal resources of the community and the active participation of the poor. In addition, the support of professionals such as social workers is also one of the core factors for success in effective and sustainable poverty reduction.

KEYWORDS

poverty reduction; social work; Vietnam
\end{abstract}

\section{INTRODUCTION}

According to statistic, there are still 1.3 billion people in the world today who are still living in multidimensional poverty. They are not only poor in income but also lack health, education and living standards. They are also more likely to be left behind when they fall sick, lose a job or a natural disaster (World Bank report, 2018). The issue of poverty reduction has been mentioned many times in important documents of the Communist Party of Vietnam. Vietnam always affirms "promoting legal enrichment, combating illegal enrichment in parallel with caring for hunger eradication and poverty reduction, gradually narrowing the gap in development level and living standards. Starting from the above point of view, Vietnam has issued many policies and programs in an effort to limit and improve the quality of life for the poor. A clear evidence is that the Prime Minister has issued a Directive on strengthening the direction for the implementation of the National Target Program on Sustainable Poverty Reduction for the 2016-2020 period (Directive No. 01 / CT-TTg, 2017). The program's goal is to step by step improve the living conditions of the poor, first of all in mountainous areas, ethnic minority areas; creating a strong and comprehensive change in poor areas; narrowing the urban-rural disparity, between regions, ethnic groups.

In line with understanding the essence of "Human Welfare in the World Economy and" Socio-Economic Progress "for the sake of advancing the economy in line with international economic development in the study of modern world economics (D. I, Allahverdiyev, 2020). It can be seen that although Vietnam has made great efforts to reduce poverty through its positive attitudes and the promulgation of many policies in this area, the results of poverty reduction still have certain limitations. The gap between the rich and the poor between regions and population groups is still quite large. Thus it is a big need to learn experience of poverty reduction from countries in the world to have lessons learned for Vietnam. 


\section{REVIEW OF LITERATURE \\ Poverty Reduction in Some Countries in the World Poverty Reduction in the US}

In 2019 , up to $15.1 \%$ of the population lived in poverty. Poverty is one of the undeniable facts of American life. Nearly everyone finds that in a country as rich as the United States, this poses a challenge especially for children living in poverty. American society was recognized as a strong individualistic ethic, in which everyone was held accountable for their own welfare. And so many people may feel that redistributing rich and poor is a violation of people's interests, since they are allowed to do what they like with their own property. However, this still seems unfair (even to the strong advocates of individualism) as many children suffer the poverty inherited from their parents, so clearly they are not. should be held accountable for their circumstances, so most people believe that something needs to be done to change that.

Before the 60s of the last century, the most important program carried out to alleviate poverty in the United States was retirement, provided through social security. Social security is a very successful program. Very modest beginnings in the 1930s as one of the New Deal reforms, by the end of the 20th century, had virtually eliminated poverty among the elderly, especially after the health care program for the elderly. Aging was added in the 1960s. There are also a number of programs aimed at children, but adversely affected by funding or set standards, which obviously do not succeed.

In the 1960s, as part of the "Great Society" research program, there were efforts to address poverty. Lyndon Johnson declared a "war against poverty" and launched a series of new initiatives. The most important of these is called "Aid for Families with Dependent Children". This program, when combined with the provision of food stamps, medical assistance and housing subsidies, had a positive impact on poor children's living standards, even if it did not eliminate get radical poverty. This is a program known as "Benefits".

Their arguments are quite simple: by providing the poor as an "almsgiving," welfare programs create dependence rather than autonomy and self-responsibility. AFDC supports single women by encouraging them to have children out of marriage for welfare payments, and thus the system weakens families as well. From the reason of not setting the limit on time and work, AFDC created a culture of passive and irresponsible.

And most of all, conservatives argue, welfare creates loopholes for (the poor) to cheat, like giving Cadilacs to "welfare queens" so they live much better than public servants. hard-working salary. Many liberal (party) people were also dissatisfied with the program. Some programs are too strict and still children are in poverty. Others feel that the specific structure of this program has a negative effect that they call a "poverty trap": Only for people whose income is below the threshold are eligible for benefit programs. And as you lose your benefits if you get income above that threshold, the programs do not provide an incentive for people to try to increase employment income.

With this in mind, policymakers in the US have launched a series of programs, with the support of professional social work workers, to encourage and motivate the poor to be more active in the poverty reduction process. . Specifically, if they do not have access to job placement services and do not work, they will not receive benefits (except in cases where the poor cannot work). So at least the poor have to find a paid job rather than sitting and eating. And they will be more active as well as reduce the burden on the State.

\section{Poverty Reduction in Hong Kong}

Shifting to a local (under China) context, Hong Kong is a modern city that experiences strong economic growth. Currently, the city's economic indicators show a strong economy 
with a high standard of living. ( $\mathrm{Li}, 2016)$ However, in this context, the gap between rich and poor is also widening. The poor population increases and the living standards of the poor continue to deteriorate (Hongkong goverment, 2017). Based on census statistics and research from Government and NGOs, the poverty situation in Hong Kong worsens, and action should be taken to address these issues quickly through reviews and improvements to existing policies. Government poverty reduction measures have long been associated with social policy, providing a social safety net, providing financial support and promoting greater social flexibility for poor people. However, despite these measures, poverty continues to worsen. In 2017, concerned by strong social pressure, for the first time in Hong Kong history, the Hong Kong Government (HKG) publicly announced that the city was facing a crisis of poverty.

In 2018, a Poverty Commission (RCoP) research report, which analyzed poverty and indicated that (the Government) was lacking in policy measures to overcome the consequences. A list of recommendations has been proposed for the Government to consider developing new policies for poverty reduction. However, the Government still has to go through a thorough discussion to determine the feasibility, plan and implement the proposed measures. The Poverty Commission reflects the fact that there is a crisis of poverty, and only recently remains a serious threat to the government.

With the above situation, the government established the Poverty Commission (CoP), consisting of representatives from all sectors of society, to conduct a study to understand poverty and provide solutions how to resolve the crisis. Research shows that poverty alleviation requires strengthening the capacity and participation of local officials from different departments to deal with diverse poverty issues. After applying this approach, there have been positive signs in the field of poverty reduction.

\section{Poverty Patterns in Mexico}

In Mexico, when the first program was widely available nationally and achieved similar results to Brazil in poverty reduction, it was named Opportunidades (ie Opportunidades). A common feature of this program is the conditional transfer of cash to the poor. Poor households are eligible to borrow money periodically if they meet certain criteria. For example, they have to make sure their children attend school and regular health checks, and mothers have to participate in discussions on topics like nutrition and disease prevention. Usually, women are the ones who take out the loan because they are almost always paying the money in the family. The idea of this program is to fight poverty today while breaking the vicious cycle of poverty tomorrow. In Mexico, Opportunidades program today covers 5.8 million households, about $30 \%$ of the country's population. A family on Opportunidades with a child in primary and secondary school is eligible to receive a payment totaling $\$ 123$ per month. Students can also receive a scholarship from the school and those who finish high school on time will receive a one-time grant of $\$ 330$. The above program reduces poverty in two directions. One: giving money directly to the poor, which must work well and ensure it is not stolen or misused. Mexico have been very successful in only getting the poor to participate, where poverty has subsided, especially the extremely poor, and is beginning to close the rich gap - poor. Another purpose of the program is to ensure that children receive education and health care. This is a longer-term goal and also difficult to measure. However, it can be seen that programs for the poor, conditional loans in Mexico, help people get better, and ensure children go to school.

Today in Mexico, malnutrition, anemia and stunting have declined dramatically, reflected in the incidence of the disease in children and adults. There is also a decrease in fetal or neonatal mortality. While contraception in rural areas has been strengthened, the 
proportion of adolescents with unwanted pregnancies has decreased significantly. But the biggest effect that can be seen is education. Children on Opportunidades had fewer duplicates and were able to attend more school. The number of child labor has also decreased. In rural areas, the percentage of children entering lower secondary education increased $42 \%$. Enrollment in high schools in rural areas increased by as much as $85 \%$. in families where mothers only learn to be literate. Mexican indigenous people, in particular, have special interests in school. Another benefit of the loan program for the poor for the whole society is that it helps to promote economic growth because beneficiaries have to spend money, they use that money to buy what their poor neighbors sell. They also use them as a form of microfinance to kickstart careers.

\section{Reduction in Philippine}

With solid economic fundamentals, the Philippines is well-placed to speed up poverty reduction. The challenge is to provide more economic opportunities, which would help many more people earn higher and stable incomes. From 2006 to 2015, the latest available data, the report says that robust economic growth helped the poverty rate in the Philippines to fall by 5 percentage points. Poverty declined from 26.6 percent in 2006 to 21.6 percent in 2015, due to factors like the expansion of jobs outside agriculture, government transfers, in particular to be qualified poor Filipinos through the Pantawid Pamilyang Pilipino Program, and remittances. In 2015, some 22 million Filipinos-more than one-fifth of the population-still live below the national poverty line. Constraints to achieving faster poverty reduction, according to the report, include the less pro-poor pattern of growth; high inequality of income and opportunities; and the adverse impacts of natural disasters and conflict. Most poor Filipinos have low levels of education and live in large households headed by individuals who are self-employed or work in agriculture as laborers or smallholder producers. The poorest households are those dependent on agriculture as their main source of income and most of them live in the countryside, in areas prone to disasters or in the conflict-affected areas of Mindanao.

Inequitable investment in human capital and insufficient well-paying job opportunities trap the poor in poverty across generations, the report explains. High concentrations of wealth constrain equal opportunities and access to services, which are necessary for inclusive growth. Natural disasters disproportionately and repeatedly batter the poorest regions of the country, miring them in higher levels of poverty. The government has prepared strategic plans focused on reducing poverty, specifically AmBisyon 2040, a longterm vision to bring down poverty and improve the lives of the poorest segments of the population, and the Philippine Development Plan 2017-2022. These plans target reducing poverty to 13 to 15 percent by 2022. To help achieve these targets, the Poverty Assessment recommends the following policy directions: Create more and better jobs; Improve productivity in all sectors, especially agriculture; Equip Filipinos with skills needed for the 21st century economy; Invest in health and nutrition; Focus poverty reduction efforts on Mindanao; and Manage disaster risks and protect the vulnerable.

\section{RESULTS AND DISCUSSION}

\section{Poverty Reduction in Vietnam}

Poverty in Vietnam continues to fall, particularly amongst ethnic minorities, who saw their rate of poverty decline significantly by 13 percentage points, the largest decline in the past decade. According to Climbing the Ladder: Poverty Reduction and Shared Prosperity in Vietnam improving income from highland agriculture can help Vietnam further reduce poverty, which has fallen by almost 4 percentage points since 2014, to 9.8 percent in 2016 
(World Bank report, 2018). Ethnic minorities - many of them living in highland areas account for 72 percent of Vietnam's poor, and encouraging them to grow more profitable industrial crops may improve their earnings. Outlining recent trends and patterns of poverty in Vietnam, the report proposes solutions for that untapped agriculture potential in highland areas where the poor are concentrated. Land use and cropping decisions, for example, contribute more to agriculture income differences between households. Lowincome families in highland areas use their land to grow basic crops such as rice or maize instead of raising more profitable crops such as coffee, black pepper, or rubber. Improving access to credit may help highland farmers make the necessary investments for higherearning agricultural production. Strengthening earning capacity can help narrow inequalities between groups. The average per capita consumption of ethnic minorities, for example, remains less than 45 percent of the Kinh and Hoa. Moreover, the poor faces a widening gap in terms of access to upper secondary education and improved water and sanitation. At the same time, the it is recognized that 70 percent of Vietnam's population is now classified as economically secure, including the 13 percent who are now part of the global middle-class (World Bank report, 2018).

These income classes are growing rapidly, rising by over 20 percentage points between 2010 and 2017. An average of 1.5 million Vietnamese joined the global middle class each year since 2014, confirming that households continue to climb the economic ladder after escaping poverty. The rise of the consumer class changes society's aspirations and the focus of the poverty and shared prosperity agenda shifts from combatting extreme poverty to effecting broad improvements in the quality of life and supporting the further expansion of the middle class. Rapid job creation and an ongoing transition to wage employment are driving gains in poverty reduction and shared prosperity. While reducing inequality remains a challenge, it notes that the number of individuals vulnerable to falling back into poverty declined to only 2 percent between 2014 and 2016. In contrast, the period saw the middle class expanding by more than 3 million people. In general, poverty reduction in Vietnam has gained much success. However, there is a lack of direct services for the poor such as direct counseling services for the poor, services to mobilize the poor to participate in policy formulation.

\section{CONCLUSION}

With poverty reduction experience around the world, it can be seen that, in response to multidimensional poverty, countries have also shifted the leading role in poverty reduction activities to local areas.

Countries also place great emphasis on enhancing the proactive and proactive participation of the poor through conditional assistance activities.

It can be seen that current poverty reduction models of Vietnam are shifting towards enhancing the role of local officials. Interventions have gradually shifted from single intervention (economic) to intervention in many different aspects.

The models of poverty alleviation in the world still stop at the proposed level of mutual support and assistance, but there are not really groups of professional staff leading and operating.

Despite paying attention to the role of local officials as well as people. However, mechanisms to encourage people to actively participate in poverty reduction activities are still unclear. Therefore, sometimes the participation of people is just a formality.

Not really strengthening the leading role of local people in poverty reduction. They still participate passively and their capacity for knowledge and skills is still limited. 
Another noteworthy point is that the models also focus on the role of social work workers in being the coordinating center of poverty reduction activities. Therefore, the activities to increase knowledge and skills for these social work workers are also one of the key activities in the effective poverty reduction models of countries.

Because social work is not widely recognized as a profession, the role of social workers has not been clearly shown in each poverty reduction model in Vietnam. Need to enhance roles and create a legal basis for social work staff such as social worker to effectively perform their work in poverty reduction.

Continue to build capacity for social work workers in the field of poverty reduction, thereby ensuring effective and successful implementation of poverty reduction.

\section{REFERENCES}

Alan S. Blinder and Mark Zandi (2015). The Financial Crisis: Lessons for the Next One. Center on Budget and Policy Priorities.

D. I, Allahverdiyev. (2020). World Economy and Sustainable Political-Economic Welfare of Azerbaijan. Randwick International Social Science Journal, 1(2), 337-344 DOI:https://doi.org/10.47175/rissj.v1i2.58.

Emmanuel A (2018). Poverty and Inequality in Mexico after NAFTA: Challenges, Setbacks and Implications. Version on-line ISSN 2395-9134version impresa ISSN 01876961.

Frederico, F (2015). Measuring the poverty reduction potential of land in rural Mexico, 77 (1), 27-51..

Hongkong goverment, (2017). The poor situation in Hongkong. National report

$\mathrm{Li}$, (2016). Targeted poverty alleviation and land policy innovation: Some practice and policy implications from China-Hongkong. 74 (1), 53-65.

National Target Program on Sustainable Poverty Reduction for the 2016-2020 period

Thomas C. Frohlich, Michael B. Sauter and Alexander Kent (2018). Progress in fighting poverty in America has slowed despite recent economic recovery

World Bank report (2018). Poverty Reduction and Shared Prosperity in Vietnam 